\title{
308 超望性二相ステンレス岸崖鋼の固相接合について
}

\section{Solid-state Diffusion Bonding of Superplastic Duplex Stainless Steel with Carbon Steel}

\author{
学 ○山田 雅之 （愛媛大・院）正 荻山 博之 （愛媛大） 正 佃 等 （愛媛大）
}

Msayuki YAMADA, Ehime University, Bunkyou-cyo 3, Matuyama, Ehime

Hiroyuki OGIYAMA, Ehime University

Hitoshi TUKUDAEhimeUniversity

\section{1 諸 言}

二相ステンレス鋼はフェライト $(\alpha)$ 相とオーステナイト $(\gamma)$ 相から成っており, 応力腐食割れや孔食に対する高い抵抗 を持つと同時に高い強度を示す.一方，本鋼に特定の加工熱 処理を施すと，適切な温度範囲，ひずみ速度条件下において 超塑性と呼ばれる高い延性を示すことが知られている. その 超塑性の優れた塑性流動性を利用することによって低負荷, 短時間での固相接合が期待される.

そこで本研究では，超塑性現象が得られる二相ステンレ 又鋼と炭素鋼 S45C，S15C との固相接合を行い，接合挙動に 及ぼす温度, 荷重, 時間, 表面粗さなどの諸因子の影響につ いて検討した. また，このような異種金属材料の接合体は接 合部において複雑な組織変化を示し，これに伴い接合体の機 械的特性が変化することが予想され，このことについても検 討を加えた.

\section{2 供試材及び実䀫方法}

2.1 試験片作成 供試材には市販の二相ステンレス鋼 (SUS329J1) と炭素鋼 S45C，S15C を用いた. 二相ステンレ 又鋼は超塑性現象を得るために前処理として， $\alpha$ 単相化処理 (1573K，一時間保持後, 水冷)を施し, 75\%の圧下率で冷間圧 延を施した. 最終的に厚さ $8 \mathrm{~mm}$ の平板を作成し, 試験片の 接合面は圧延方向と垂直な面にした，そして，異なる接合面 の粗さを得るため, 接合面に片削り盤加工, エミリー及びバ フ研磨を施した.

2.2 実験方法 接合条件は温度 $1273 \mathrm{~K} \sim 1373 \mathrm{~K}$ ，時間 60 $\sim 900 \mathrm{~s}$, 圧縮荷重 3 9MPa 及び表面粗さ $\mathrm{R}_{\max } 0.02 \sim 320 \mu$ $\mathrm{m}$ で行った. 接合試験は $100 \mathrm{~Pa}$ の真空度で, $1 \mathrm{~K} / \mathrm{s}$ の条件下 で接合温度まで昇温し, 均熱化のため 10 分間保持した後, 圧 縮荷重をかけることにより実施した. 負荷応力が設定した応 力となった時点より接合時間をとり, 終了後直ちに荷重を除 荷して試験片を空冷した。

硬さ試験はマイクロビッカース試験機を使用し，荷重は $50 \mathrm{~g}$ を用いた. 引張り試験の試験条件は常温で, ひずみ速度 $3.0 \times 10^{-4} \mathrm{~mm} / \mathrm{s}$ で行った. 疲労試験は, 常温で繰返し速度 $20 \mathrm{~Hz}$ の正弦波で, $\mathrm{R}=0$ の条件で行った. なお, $\mathrm{S} 45 \mathrm{C}$ との接 合体を $\mathrm{A}$ 材， $\mathrm{S} 15 \mathrm{C}$ との接合体を B 材と呼ぶことにする.

\section{3 実験結果及び考察}

\subsection{A 材の接合強度に及ぽす諸因子の影䈏}

Fig1 は異なる温度の接合時間と強度の関係を示す. ある一 定の時間において温度が高い方が高い強度が得られた. 温度 の上昇は材料の降伏応力を低下させ， クリープ変形や原子の 拡散を活性化し接合強度が上昇すると考えられる.

Fig2 は接合荷重が接合強度に及ぼす影響を示す. 圧縮荷重 が増加するにつれて接合強度も増加しているのか確認できる. これは, 圧縮荷重の増加に伴い接合の塑性流動性による密着 化が促進され強度が上昇すると考えられる.

Fig3 は異なる圧縮荷重の接合時間亡変形率の関係を示す. Fig3より加圧荷重と接合時間が大きくなくなればなるほど変 形度が高くなっている. 変形度が高いと実用的な面で望まし くないと考えられるので，接合強度だけでなく変形率からも 最適接合条件を考える必要がある.

Fig4 は表面粗さと接合強度の関係を示す. 表面粗さ $\mathrm{R}_{\max } 0.2 \mu \mathrm{m}$ 及び $0.32 \mu \mathrm{m}$ では, 同じ熱履厨を受けた $\mathrm{S} 45 \mathrm{C}$ の母材と同じ強度が得られた. そして， $\mathrm{R}_{\max }$ が大きくなると

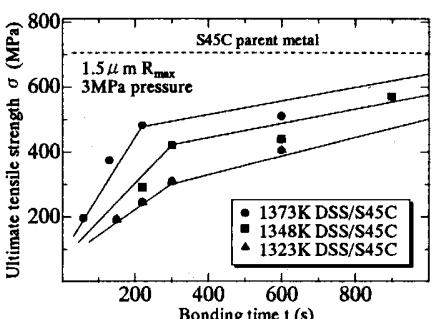

Fig.1. Relationship between bonding strength and time at different temperatures.

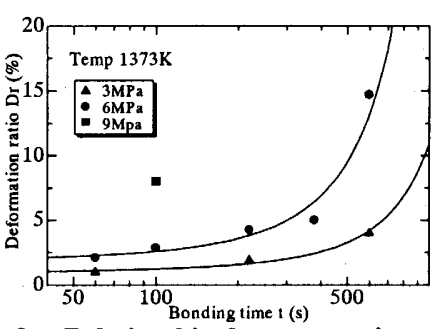

Fig3. Relationship between tatio and bonding time at different pressures.

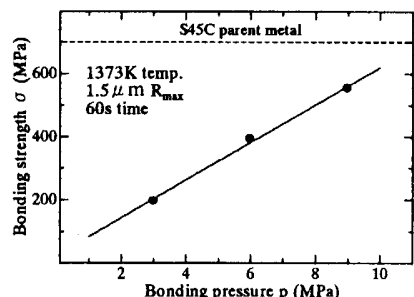

Fig2. Relationship between bonding strength and pressure

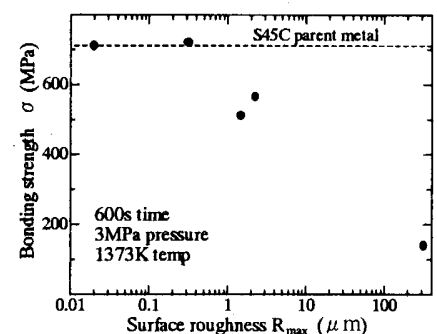

Fig.4. Relationship between bonding strength and surface roughness. 強度が明らかに低下することが確認できる. これは, 表面粗 さが大きくなれば，接合時十分に密着できずに隙間ができる ため接合時間が低下することが起因しているものと考えられ る.

\section{2 最適接合条件}

以上の結果より $\mathrm{A}$ 材の最適接合条件は温度 $1373 \mathrm{~K}$, 時間 $220 \mathrm{~s}$, 压縮荷重 $3 \mathrm{MPa}$ 及び表面粗さ $\mathrm{R}_{\max } 0.32 \mu \mathrm{m}$ であり, その時の変形度は $1 \%$ であることが確認された. また, 接合温

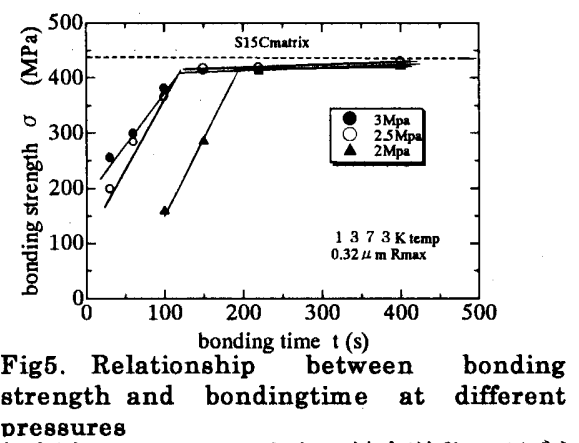

度や表面粗さはS45C, S15C ともに接合挙動に及ぼす影響は 変わらないと判断できるので, 荷重と時間だけ変化させ B 材 の接合を行った.

Fig5 はB 材における㴼荷重と接合強度の関係を示す. 図 より, 荷重が $3 \mathrm{MPa}$ と $2.5 \mathrm{MPa}$ では $120 \mathrm{~s}$ 付近で母材とほぼ 同程度の強度まで引張り強度が上昇した. 従って, 二相ステ ンレス鋼と $\mathrm{S} 15 \mathrm{C}$ との最適接合条件は温度 $1373 \mathrm{~K}$, 時間 $150 \mathrm{~s}$, 压縮荷重 $2.5 \mathrm{MPa}$ 及び表面粗さ $\mathrm{R}_{\max } 0.32 \mu \mathrm{m}$ と考えられる. このことより $\mathrm{S} 15 \mathrm{C}$ は S45C よりさらに低負荷, 短時間で接 合することができるため, 接合に適した材料であることがみ こめられた。

\section{3 接合界面近傍の組䋘特性及ひ硬さ特性}

Fig6(a)は A 材の接合界面近傍の組織写真を示し, Fig6(b) 
はB 材の接合界面近傍の組織写真を示す.

炭素鋼の標準組織としてパーライト(黒い組織)とフェライ ト(白い組織)が見られる. 接合界面近傍においてはパーライト がなくフェライト(白い領域が見られる.これは, 脱炭領域で あると考えられる. また，二相ステンレス鋼側には接合界面 近傍にクロム炭化物(黒い領域が見られる。

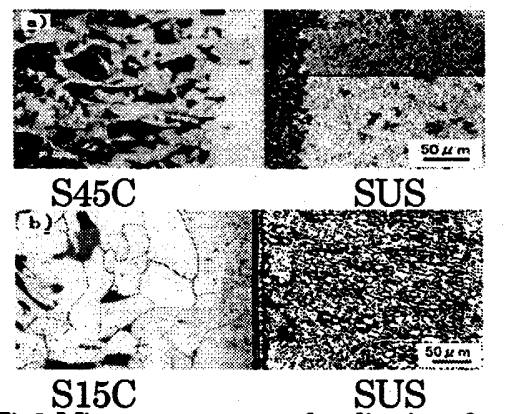

Fig6. Microstructures near bonding interfaces

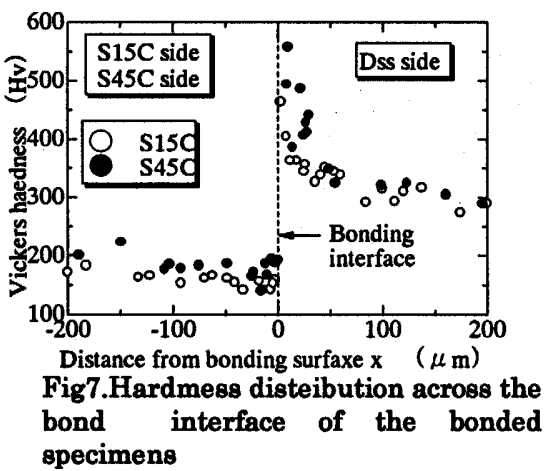

Fig7 は雨接合体の代表的な硬さ分布を示す. 図より，二相 ステンレス鋼側においては, 両接合体とも接合面に向かって 硬さが増加しているのが分かる. しかし，B材の方がA 材に 比へて変化の領域が少ないのが分かる. また炭素鋼側におい ては，A 材は接合面に向かって硬さが低下しているが， B 材 はほとんど変化が見られないことが確認できる.

これより，この硬さの変化の原因は，加炭及ひ脱炭現象に よるものだと考えられる. 二相ステンレス鋼よりも比較的高 い濃度の炭素(C)が含まれる炭素鋼は原子の拡散により，その 炭素が二相ステンレス鋼側に移動し脱炭現象により炭素鋼側 の硬さが低下する. それに対して，二相ステンレス鋼側では 加炭現象により硬くなる. つまり, A 材には硬化及び軟化領 域が存在する. それに対して B 材は A 材よりも炭素含有量が 少なく，硬さに影響するパーライトが少ないために炭素鋼の 硬さの変化に影響がでなかったと考えられる.

3.3 引張り特性

Table.1 Tensile properties of bonded specimen

\begin{tabular}{|c|c|c|c|}
\hline Specimen & $\begin{array}{l}\text { Tens i le strength } \\
(\mathrm{MPa})\end{array}$ & $\begin{array}{c}\text { Elongat ion } \\
(\%)\end{array}$ & $\begin{array}{l}\text { Reduction of } \\
\text { area (\%) }\end{array}$ \\
\hline SUS Matrix & 707.9 & 45.8 & 53.5 \\
\hline S45C Matrix & 715.4 & 20.6 & 18.8 \\
\hline A specimen & 708.8 & 10.1 & 11.1 \\
\hline S15C Matrix & 434.3 & 33.5 & 60.6 \\
\hline B specimen & 418.2 & 25 & 59.4 \\
\hline
\end{tabular}

Table1 は両接合体の引張り特性を示す. また，母材との比較 のため同じ熱履歴を受けたそれぞれの母材も表に載せている. Table1より両接合体ともに母材と同程度の優れた引張り強度 が得られた. しかし，A 材は伸び, 絞りともに母材より低い 值を示す. それに対して，B 材は伸び，絞りともに母材とほ ぼ同じ値を示した.
また，接合体の破断場所では $\mathrm{A}$ 材が接合界面付近であるの に対し，B 材は接合界面から離れた炭素鋼側で破壊が起こっ ていることが確認できた.

この結果から A 材においては接合界面付近で低強度部である 脱炭層を含むのにもかかわらず母材とほぼ同程度の強度を示 す.これは，本研究のように局所的な低強度の層を持つ材料 は引張り荷重を受けると, 低強度部で先行して生じる塑性変 形か強度の高い隣接部によって拘束され，低強度部は多軸引 張り応力状態になる. それにより材料を破壊するのに必要な 応力は低強度部そのものと比べて大きくなると考えられる.

\section{4 波労特性}

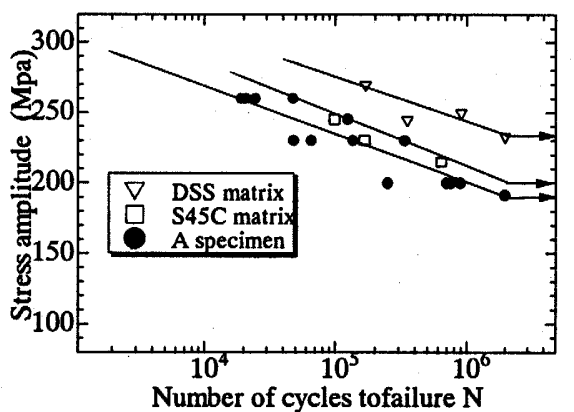

(a) DSS, S45Cmatrix, A specimen

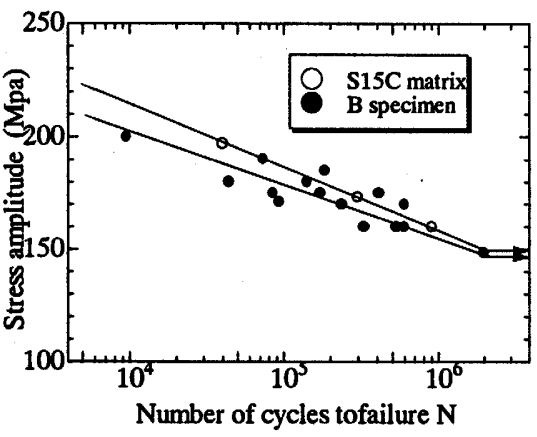

(b) S15Cmarrix, B specimen

Fig8 $\mathrm{S}-\mathrm{N}$ curves of bonded specimens and parent metals

Fig8(a), (b)は両接合体の S-N曲線を示す. 引張り特性と 同様に同じ熱履歴を受けたそれぞれの母材も載せてある.

Fig8(a)より，A 材は母材に比べて少し強度が低下している のが認められる. さらに，母材よりデ一タのばらつきが大き いことが分かる. これは接合界面付近の組織の不均一性, 特 に低強度部の脱炭首において優先的にき裂が倠展, 成長する ため, 疲労特性に悪影響を及ぼすと考えられる. また, Fig8(b) より B 材は母材とほぼ同程度の強度がえられたが, 少しのば らつきが確認できる.これは, パーライトが少ないために硬 さには変化が見られなかったが, やはり脱炭層における組織 の不均一性が影響していると考えられる.

つまり，接合時間が長くなると脱炭層の幅も大きくなると 考えられるので, 時間の短縮が必要不可欠である. その改善 方法の有効な手段として, 本研究のような超塑性材料の利用 が考えられる. さらに接合面同士の密着のしやすさを考える と，延性に優れた材料が接合に適していると考えられる.

\section{4 結言}

超塑性を発現させるため, 特別な前処理を施した超塑性二 相ステンレス鋼を用い，炭素鋼(S45C, S15C)との固相接合を 行い, 接合強度に及ぼす諸因子の影響を検討した. その結果, 特にS15C との接合体では極めて低負荷, 短時間の接合条件 で母材と同程度の引張り強度を持つ接合体が得られた。 疲労 強度については S45C 接合体は母材よりやや低下するが, $\mathrm{S} 15 \mathrm{C}$ 接合体では母材とほぼ同程度の強度が得られた. 